\title{
The Microbial Community of a Radon Hot Spring
}

\author{
Roberto P. Anitori \\ Department of Biological Sciences, Macquarie University, North Ryde, \\ 2109, Australia \\ Cherida Trott \\ School of Biological Sciences, Private Bag 90219, University of Auckland \\ David J. Saul \\ School of Biological Sciences, Private Bag 90219, University of Auckland \\ Peter L. Bergquist \\ Department of Biological Sciences, Macquarie University, North Ryde, \\ 2109, Australia \\ Malcolm R. Walter \\ Department of Earth and Planetary Sciences, Macquarie University, \\ North Ryde, 2109, Australia
}

\begin{abstract}
Paralana is an active, radon-containing hot spring situated in a region of South Australia's Flinders Ranges with a long history of hydrothermal activity. Gas bubbling into the pool is composed of radon (from the radioactive decay of radium), nitrogen, carbon dioxide, and trace helium and hydrogen. The microbial composition of mat and biofilm samples from Paralana was determined using culture-independent $16 \mathrm{~S}$ rRNA techniques. We have previously demonstrated that the hot spring contains a diverse bacterial community. Here we summarise these findings and report on the Archaea identified in Paralana. Archaeal inhabitants include members of the Crenarchaeota and Euryarchaeota kingdoms.
\end{abstract}

\section{Introduction}

Studies of the microbiota inhabiting hot springs provide insights into the origin, evolution and biodiversity of life on Earth. Investigations of this kind have other astrobiological implications, such as the interpretation of presumed biomarkers in ancient terrestrial hydrothermal systems, the search for past or present microbial life on Mars, and planetary protection issues (via analysis of radiation-resistance mechanisms). Despite these benefits, little work has been conducted on hot springs in Australia. The Paralana hot spring is the only modern manifestation of hydrothermal activity in the Mt. Painter region of South Australia's Flinders Ranges, an area that has undergone extensive hydrother- 
mal action over the past 300 million years. The region is highly mineralised, with a predominance of uranium- and radium-containing radioactive minerals. The hot spring is unique in that it is a radon-rich environment that supports a flourishing microbial community (Anitori et al. 2002). Radon levels (alpha radiation) are higher in the gas than in the spring water: $29000 \mathrm{~Bq} / \mathrm{L}$ versus $2000-5800 \mathrm{~Bq} / \mathrm{L}$, respectively. The spring water also contains measurable levels of gamma radiation (Grant 1938; Beverley 1998). In addition to ionising radiation, the microbial community in Paralana is subjected to elevated water temperatures $\left(48-63^{\circ} \mathrm{C}\right)$ and ultraviolet radiation. We provide a description of the microbial community of the Paralana hot spring, determined by cultureindependent molecular genetic analyses using the gene coding for $16 \mathrm{~S}$ ribosomal RNA (16S rRNA), the small subunit of the prokaryotic ribosome. This technique produces a qualitative/semi-quantitative description of mixed microbial communities. Although it suffers to some degree from PCR and DNA extraction bias, the method detects the large fraction of "unculturable" microorganisms (estimated at greater than $99 \%$ ) that cannot be found using traditional culture methods (sometimes referred to as "The Great Plate Count Anomaly"; Staley \& Konopka 1985). Here, we focus on the Archaea identified, and describe their phylogenetic relationships.

\section{Materials and Methods}

\subsection{The Paralana Hot Spring}

The Paralana spring has been described elsewhere (Anitori et al. 2002). In summary, the hot spring system consists of two small, interconnected pools: the Source Pool $(\sim 1 \times 2 \mathrm{~m})$ into which the source water and gas emerge, and a Main Pool $(\sim 10 \times 5 \mathrm{~m})$, formed from Source Pool water which flows around a boulder and through sediment. Samples for analysis (Table 1) were collected from numerous coloured benthic and floating mats and biofilms present in both pools.

\subsection{Molecular Genetic Procedures}

Sample collection, DNA extraction, Bacteria -specific genetic analyses, DNA sequencing and database analysis were essentially conducted as previously described (Anitori et al. 2002). Phylogenetic analyses were performed using PAUP* software (Swofford et al. 2002). PCR method\#1. Amplification of community 16S rRNA genes from Archaea utilised domain-specific PCR primers ASF (5'CCA GGC CCT ACG GGG CGC A-3 ${ }^{\circ}$ ) and ASR (5'-GTG TGC AAG GAG CAG GGA C-3 $3^{\circ}$ ). PCR cycling conditions were: $94^{\circ} \mathrm{C}$ for 3 min (1 cycle); $94^{\circ} \mathrm{C}$ for $50 \mathrm{~s}, 55^{\circ} \mathrm{C}$ for $50 \mathrm{~s}, 72^{\circ} \mathrm{C}$ for $2 \mathrm{~min}(25$ cycles $) ; 72^{\circ} \mathrm{C}$ for $7 \mathrm{~min}$ ( 1 cycle). The PCR reaction mix contained sample DNA (ca. $100 \mathrm{ng}$ ), $20 \mathrm{mM}$ Tris-Cl, $\mathrm{pH} 8.4,50 \mathrm{mM} \mathrm{KCl}, 2 \mathrm{mM} \mathrm{MgCl} 2,200 \mu \mathrm{M}$ of each dNTP, $10 \mathrm{pmol}$ of each primer, and $1 \mathrm{U}$ of PLATINUM Taq DNA polymerase enzyme (Invitrogen). PCR method\#2. Similar to method\#1, but with the following changes: primer ASR replaced by Arch1378 (5'- GTG TGT GCA AGG AGC AGG GAC -3'); 30 cycles instead of 25 , and a 5 - 10 fold increase in input sample DNA. 
Table 1. Sample descriptions

\begin{tabular}{clc}
\hline Sample1 & Description & Temp. $\left({ }^{\circ} \mathbf{C}\right)$ \\
\hline A & brown biofilm + sediment & $60-63$ \\
B & sediment 2-3 cm under A & $60-63$ \\
C & black mat + sediment & 48 \\
D & grey sediment (3-4 cm down) under blue-green mat & 49 \\
E & diaphanous biofilms and slimy mats + sediment & 60 \\
F & white filamentous encrustation on sticks & 60 \\
& (on pool bottom) + sediment & 59 \\
G & white biofilm on green mat & 53 \\
H & floating green and green-yellow mat & 48 \\
I & benthic green-yellow and emerald green & \\
& soft mat forming sheets and pinnacles & \\
\hline \hline
\end{tabular}

1 All samples were $\sim \mathrm{pH} 7$; samples $\mathrm{A}$ to $\mathrm{H}$ were obtained from the Source Pool; sample (I) was from the Main Pool.

\section{Results}

\subsection{Bacteria}

Bacterial 16S rRNA sequences were identified in all Paralana samples analysed, with representatives of nine bacterial divisions detected: Cyanobacteria, $\beta$ - and $\delta$-Proteobacteria, the CFB group, Low $\mathrm{G}+\mathrm{C}$ Gram-positives, Nitrospira, Green-non sulfur bacteria, Green sulfur bacteria, OP8 and OP12. The first seven are confirmed divisions; the latter two are candidate divisions (Anitori et al. 2002).

\subsection{Archaea}

PCR amplification using PLATINUM Taq and PCR method\#1 resulted in products of the correct size $(\sim 1 \mathrm{~kb})$ in samples A, C, D, E and F. The product obtained in samples B, G, H and I was not of sufficient quantity to be used for recombinant $16 \mathrm{~S}$ rRNA library construction. No PCR product was obtained in a DNA extraction negative control. 16S rRNA libraries were constructed for samples A, C, D, E and F, and approximately 230 cloned $16 \mathrm{~S}$ rDNA inserts (genes) were screened using HaeIII Restriction Fragment Length Polymorphism (RFLP; used to determine the diversity of $16 \mathrm{~S}$ rRNA genes in each library). Recombinants representing dominant RFLP patterns (ribotypes) were selected for DNA sequencing. Table 2 shows the taxonomic affiliation of dominant Paralana sequences \#D5A, \#E9G, and \#F4G, as suggested by sequence database matches. These placements were confirmed by Maximum Likelihood phylogenetic analysis (Fig. 1). \#F4G had good bootstrap support for its position among the halophilic (salt-loving) Euryarchaeota (Fig. 1A); \#D5A and \#E9G grouped within a well-supported clade of uncultured thermophilic (heat-loving) Crenarchaeota from a wide variety of environments including hydrothermal springs (Fig. 1B). The \#D5A, \#E9G, and \#F4G sequences dominated in the Source Pool: \#D5A represented $87 \%$ and $55 \%$ of the $16 \mathrm{~S}$ rRNA genes examined in, respectively, samples D (73/84) and E (28/51); \#E9G represented $16 \%$ of sample $\mathrm{E}(8 / 51)$; and \#F4G was $22 \%$ of sample F (9/41). 
By using a slightly modified PCR assay (PCR method\#2), correct-sized $\mathrm{PCR}$ products of sufficient quantity for cloning were obtained from Paralana samples B, G, H and I. ARDRA and/or sequence analysis of 30 recombinants following 16S rRNA library construction indicated the presence of sequences equivalent to \#D5A, \#E9G, or \#F4G, as well as other related sequences. Also, a Methanospirillum spp. (Euryarchaeota) 16S rRNA sequence was identified in the Main Pool.

Overall, of the 16S rRNA genes examined, approximately $50 \%$ were from thermophilic crenarchaeotes (with \#D5A accounting for over 90\%), and about $7 \%$ were from halophilic euryarchaeotes (mostly the recombinant \#F4G).

\section{ARCHAEA}

- EURYARCHAEOTA

- HALOPHILIC ARCHAEA

* Natronococcus amylolyticus subgroup

- Natronococcus xingiangensis

(Paralana\#F4G, 99.5\% match over 971 bp; AF251285)

- Natronococcus amylolyticus

(Paralana\#F4G, 98.9\% match over 971 bp; D43628)

\section{- CRENARCHAEOTA}

- THERMOPHILIC CRENARCHAEOTA

* Thermofilum pendens subgroup

- uncultured Obsidian Pool clone pSL4

(Paralana\#E9G, 96.8\% match over 942 bp; U63341)

- uncultured anaerobic digestor clone vadinDC69

(Paralana\#D5A, 92.7\% match over 934 bp; U81774)

- uncultured subsurface clone Arc. 43 from Hanford, USA

(Paralana\#D5A, 95.7\% match over 492 bp; AF005758)

Table 2. Taxonomic identity of dominant archaeal 16S rRNA sequences identified in the Paralana hot spring. Based on BLAST, FASTA and RDP database searches of GenBank. The final term in each database match (e.g. AF251285) is the GenBank accession number.

\section{Discussion}

Paralana supports a wide diversity of Bacteria, with members of nine divisions represented. The hot spring also contains Archaea, although only a relatively small number of unique ribotypes were detected. Whilst suggesting a comparatively limited archaeal diversity, a definitive statement cannot be made without additional studies. For example, further sequencing could reveal the existence of a number of minor sequence variants within each ribotype. 
A

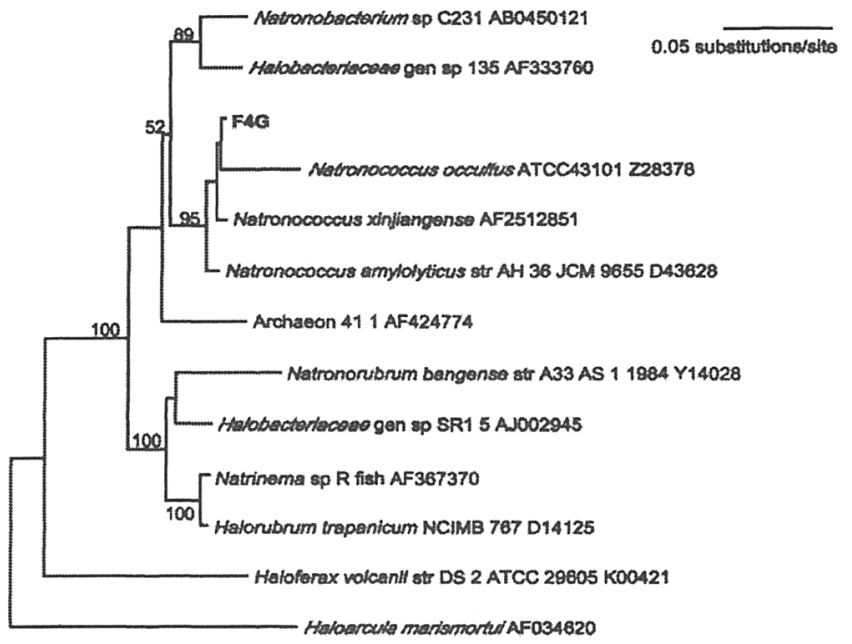

B

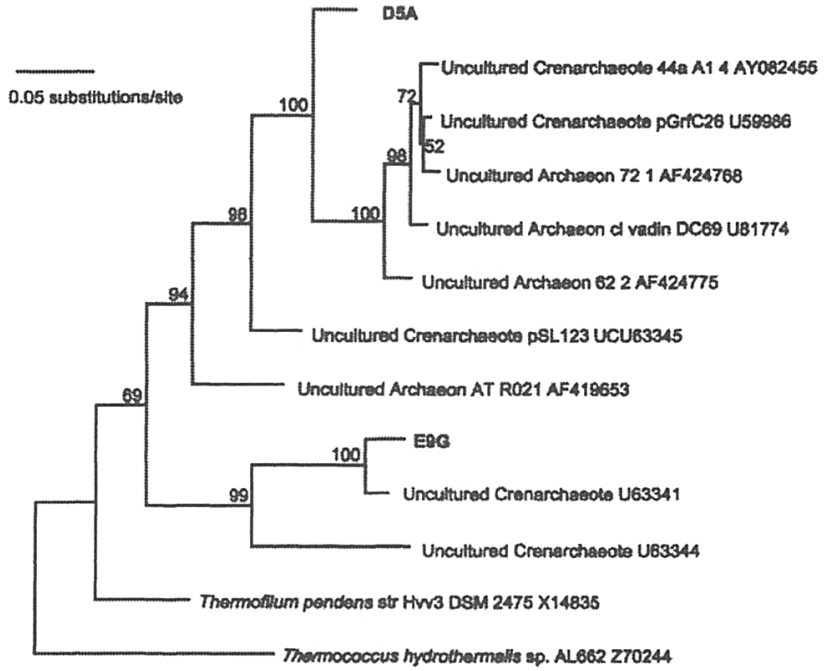

Figure 1. Maximum Likelihood trees for the Paralana archaeal sequences (in bold). The trees were generated by first inferring a tree by Neighbour Joining and using this as a starting tree for refinement under the criterion of Maximum Likelihood. Bootstrap values were generated using Maximum Parsimony with 1000 replicates and 100 random sequence additions on each replicate; values below $50 \%$ are not shown. Panel A: Phylogenetic tree of haloalkaliphilic Euryarchaeaota related to \#F4G. The tree is rooted with Haloarcula marismortui. Panel B: Phylogenetic tree of Crenarcheota related to \#E9G and \#D5A. The tree was rooted using Thermococcus hydrothermalis. 
Both sequence database matches and Maximum Likelihood phylogenetic analysis identified the two main groups of Archaea in Paralana as thermophilic crenarchaeotes of the Thermofilum pendens subgroup and halophilic euryarchaeotes of the Natronococcus amylolyticus subgroup. The former subgroup dominates in Paralana, with the most frequently represented sequence being that of recombinant \#D5A. In fact, this sequence was the most common archaeal sequence detected. The best database matches for \#D5A were with archaeal sequences identified in an anaerobic digestor (Godon et al. 1997) and in a subsurface paleosol (Chandler et al. 1998). The other dominant Paralana sequence (recombinant \#E9G) belonging to the thermophilic subgroup matched with a sequence (clone pSL4) identified in a hot spring: Obsidian Pool in Yellowstone National Park (neutral $\mathrm{pH}$, temperature range $=74-93^{\circ} \mathrm{C}$ ) (Barns et al. 1996). Halophilic Euryarchaeota only accounted for a small proportion of the Paralana recombinants analysed. The most abundant sequence (represented by recombinant \#F4G) displayed an almost perfect match with two cultured Natronococcus spp - N. xingiangensis, a halophilic extremophile originally isolated from Lake Aiding, a Chinese salt lake (Liu \& Dilbar 2000); and N. amylolyticus, an archaeon identified in a Kenyan soda lake (Lake Magadi) that can survive in both alkaline and high salt conditions (i.e. a haloalkaliphile) (Kanal et al. 1995).

The presence of Archaea in the Paralana hot spring is not surprising, particularly the dominance of sequences phylogenetically associated with thermophiles. Archaea are common in hot springs, having been identified in places such as Yellowstone National Park, U.S.A. (Barns et al. 1994), Iceland (Skirnisdottir et al. 2000) and Japan (Sako, Nunoura, \& Uchida 2001). However, this appears to be the first report of Archaea in a radon-rich hot spring environment. Radiation-resistance of the Paralana microorganisms has yet to be determined experimentally; studies are currently being planned to investigate this possibility. The presence of halophiles (Natronococcus spp.) in Paralana is interesting for two reasons. Firstly, it has been demonstrated that a halophile, Halobacterium salinarum, is resistant to ionising radiation (Shahmohammadi et al. 1997). Secondly, the Paralana water is neither hypersaline (Pirlo 2002) nor alkaline. This allows speculation on the possible presence of microniches with localised variations in salinity and/or $\mathrm{pH}$ (e.g. due to the activity of neighbouring microbes) which the Paralana Natronococcus could be exploiting.

Acknowledgments. This work was funded by the University of Auckland Research Grants Fund and the Macquarie University Research Development Grants Fund.

\section{References}

Anitori, R. P., Trott, C., Saul, D. J., Bergquist, P. L., \& Walter, M. 2002, Astrobiology, 2, 255

Barns, S. M., Fundyga, R. E., Jeffries, M. W., \& Pace, N. R. 1994, Proc. Natl. Acad. Sci. U.S.A., 91, 1609

Barns, S. M., Delwiche, C. F., Palmer, J. D., \& Pace, N.R. 1996, Proc. Natl. Acad. Sci. U.S.A., 93, 9188 
Beverley Uranium Mine Environmental Impact Statement. 1998, Heathgate Resources Pty. Ltd. Adelaide

Chandler, D. P., Brockman, F. J., Bailey, T. J., \& Fredrickson, J. K. 1998, Microb. Ecol., 36, 37

Godon, J-J., Zumstein, E., Dabert, P., Habouzit, F., \& Moletta, R. 1997, Appl. Environ. Microbiol., 63, 2802

Grant, K. 1938, Trans. Roy. Soc. S.A., 62, 357

Kanal, H., Kobayashi, T., Aono, R., \& Kudo, T. 1995, Int. J. Syst. Bacteriol., 45,762

Liu, H., \& Dilbar, T. 2000, Unpublished GenBank entry.

Pirlo, M. 2002, Ph.D. thesis, Macquarie University, N.S.W., Australia

Sako, Y., Nunoura, T., \& Uchida, A. 2001, Int. J. Syst. Evol. Microbiol. 51, 303

Shahmohammadi, H. R., Asgarani, E., Terato, H., Ide, H., \& Yamamoto, O. 1997, J. Radiat. Res. (Tokyo), 38, 37

Staley, J. T., \& Konopka, A. 1985, Ann. Rev. Microbiol., 39, 321

Skirnisdottir, S., Hreggvidsson, G. O., Hjorleifsdottir, S., Marteinsson, V. T., Petursdottir, S. K., Holst, O., \& Kristjansson, J. K. 2000, Appl. Environ. Microbiol., 66, 2835

Swofford, D. L. 2002, PAUP*. Phylogenetic Analysis Using Parsimony (*and Other Methods), Version 4, (Sinauer Associates: Sunderland, Massachusetts) 